\title{
Developing Instruments to Measure Physics Problem Solving Ability and Nationalism of High School Student
}

\author{
Mardhiyyatin Naqiyah \\ Physics Education, Graduate School, Yogyakarta State University, Indonesia, \\ mardhiyyatinnaqiyah.2017@student.uny.ac.id
}

\section{Dadan Rosana}

Physics Education, Graduate School, Yogyakarta State University, Indonesia, danrosana@uny.ac.id

\section{Sukardiyono}

Department of Physics, Facuty of Mathematics and Natural Science, Yogyakarta State University, Indonesia, sukardiyono@uny.ac.id

\section{Ernasari}

Physics Education, Graduate School, Yogyakarta State University, Indonesia, ernasari.2017@student.uny.ac.id

\footnotetext{
This research that aimed to (1) produce instruments that were feasible to measure the ability to solve physics problems and nationalism, and (2) determine the quality of instruments that have been developed. This research was conducted through four stages, namely the design, preparation of tests, test trials, and preparation of valid instruments. The instruments developed are physics problem solving ability test instrument consists of 10 number essay questions and nationalism questionnaire consists of 35 items arranged in the form of a Likert scale. This research used qualitative and quantitative analysis provided by eight validators (experts, physics teachers, and peer reviewers), and empirical validation analysis. The content validation showed that the instruments developed were in the valid category with a validity value of 1.00 for each item in the two instruments developed. Empirical validation involved 250 high school students who were randomly selected. It was found that: (1) instruments developed in accordance with Partial Credit Model (PCM) in which all items developed were in the range of 0.77 to 1.33 , (2) the instrument reliability was in the good category with in the range of 0.72 to 0.98 for both instruments, (3) the level of difficulty of problem solving ability instrument has good criteria in the range of - 0.88 to 1.81 e.
}

Keywords: evaluation instrument, problem solving, nationalism, physics, sound wave

Citation: Naqiyah, M., Rosana, D., Sukardiyono, \& Ernasari. (2020). Developing Instruments to Measure Physics Problem Solving Ability and Nationalism of High School Student. International Journal of Instruction, 13(4), 921-936. https://doi.org/10.29333/iji.2020.13456a 


\section{INTRODUCTION}

One of the scientific disciplines that has a very crucial role in the development of science and technology is physics. This requires humans to continue to improve the latest knowledge and innovations related to physics. The same thing applies to students who are required to have a more understanding of physics. Thus, the role of the teacher is very important to design learning that is more directed at mastering the concepts of physics, including in terms of preparing appropriate measuring instruments in measuring that understanding (Naqiyah, Rosana, Sukardiyono, Ernasari, 2019).

Based on Minister of Education and Culture Regulation (Permendikbud) No. 23 of 2016 concerning the standard for evaluating education, determining the learning outcomes of students in primary and secondary education covering aspects of attitudes, knowledge, and skills. This assessment aims to monitor and evaluate the process, learning progress, and continuous improvement of student learning outcomes. The assessment of aspects of knowledge can be done through written tests, oral tests, or assignments, while the assessment of aspects of attitude can be done through observations or other relevant observation techniques, such as questionnaires. Appropriate assessment can help improve the learning process, so that organizing instruments or measuring instruments of learning becomes one of the things that is crucial for an educator.

The Ministry of Education and Culture Regulation No. 22 of 2016 concerning process standards underlines that in the learning process, each activity is fully directed to be able to develop all three domains (affective, cognitive, and psychomotor). This means that in the process of acquiring knowledge, aspects of attitudes and skills cannot be ignored. Thus, the whole learning process will produce a quality person in terms of attitudes, knowledge, and skills.

One cognitive aspect that needs to be trained is problem solving ability. This aims to encourage the ability of students to produce work individually and / or in groups. In addition, the Minister of Education and Culture also recommends that one of the core competencies expected of high school students is that they are able to bring themselves to represent the national culture of the world community and be able to understand humanity and nationality knowledge (Presiden Republik Indonesia, 2016). In other words, the attitude of nationalism is one of the important aspects of attitude for every student.

In connection with the achievement of the ability to solve physics problems, some of the previous researchers found that students' ability to was still in the low category. This is mostly caused by the difficulty of students in understanding the problem and making it difficult for them to plan solutions to solve it (Mustofa \& Rusdiana, 2016). In addition, students are more focused on formulas and mathematical operations which lead them to not get the opportunity to account for opinions and answers, whereas giving more opportunities in the problem solving process can help students gain experience in solving physics problems (Sujarwanto, Hidayat, and Hartono, 2014).

Furthermore, the instruments used in measuring the ability to solve physics problems have not been maximally developed (Sinaga, 2016). Research conducted by Sinaga 
(2016) shows that the implementation of tests which conducted by teachers did not meet the requirements of a good test, for example the unavailable of question's blueprint. In addition, the development of the test has not been properly analyzed and the accuracy of the test to measure certain abilities are not known. (Sinaga, 2016)

Problems related to the problem-solving ability test instrument that is still not maximally developed are caused by several factors. One of the factor is the teacher's difficulties in making or presenting varied questions, slow in making instruments and lack of time to do empirical analysis. Measurement instruments that are less accurate will also give less accurate results. On the contrary, appropriate test preparation techniques can provide a solid foundation for conducting appropriate evaluations, which eventually will lead to a better learning process and result (Sinaga, 2016).

On the one hand, there are several problems related to student's nationalism which still often occur in schools. This can be seen from several phenomena, including the increasing prevalence of students who are proud to communicate with each other using foreign languages in their daily interactions and often they form friendship groups so that inter-group disputes often occur. This phenomenon will eventually cause the affective learning outcomes of students to be not optimal (Hikmah \& Cholisin, 2017).

On the other hand, nationalism in the assessment process has not been fully developed. Reni, Sopyan, and Hindarto (2013) write that character education values, including nationalism, are not enough if they are only integrated in learning or curriculum, but also must be integrated in assessment. Assessment as a sub-system of national education must also focus and be involved in the process of developing skills and the formation of student's character.

The domain of attitude assessment conducted in schools has not been maximally developed. Chotimah (2010) in her study wrote that teachers generally assess students' attitudes through test instruments, even though they realize that the assessment is irrelevant. In addition, most teachers do not assess the affective domain by using instruments that are relevant for attitude measurement. The teacher conducts an evaluation without a clear reference and it can be assumed that the assessment is unstructured and unplanned. This is because designing an attitude assessment instrument is not as easy as a cognitive and psychomotor assessment instrument.

Furthermore, the instrument is a tool used by researchers to collect data by taking measurements. Since the instrument becomes a data collection tool, the instrument must be well-made and able to collect data according to the needs of a study (Purwanto, 2007). Tests can be interpreted as a measurement tool to obtain student learning outcomes (Widoyoko, 2014). A good quality test is a valid and reliable test which meets the criteria requirements (Hidayat, Susilaningsih \& Cepi, 2018). The validity of the test refers to the suitability of the test with its components, the truth of the test results and interpretations, while reliability refers to the stability and consistency of the score (Angell, Kind \& Guttersrud, 2008).

Theoretical and empirical analysis needs to be done to obtain high-quality test instruments. Theoretical analysis consists of reviewing items based on aspects of 
content, construction and language. In addition, an analysis of empirical validity was obtained from the results of the PCM IRT (Item Response Theory) analysis (Mardapi, 2008)

Based on several previous studies, each variable was developed separately, both nationalism and the ability to solve problems. It also applies to the development of evaluation instruments which only measure the nationalism or the ability of problem solving in one learning process. Therefore, this research tries to combine several previous studies to see its implementation (both instruments) in one physics learning process. Thus, valid instruments need to be developed to measure the ability of problem solving and attitude of nationalism in physics learning process simultaneously.

Permendikbud No 22 of 2016 concerning the standard process underlines that in the learning process, each activity is fully directed to be able to develop all three domains (affective, cognitive, and psychomotor) as a whole. This means that in the process of acquiring knowledge, aspects of attitudes and skills cannot be ignored. The suggestion indicates that a learning process requires instruments that are able to measure all three aspects. In line with this, the measurement process using the two instruments developed in this study was carried out after the learning process was carried out. The learning process uses a problem based learning model

Furthermore, analyzing test instruments is an activity carried out to improve the quality of test questions that have been written. The quality of the instrument can be seen from validity and reliability (Nitko, 1996). Validity means the accuracy of a test in carrying out its measurement function, while reliability is the extent to which measurement results can be trusted (Azwar, 2012). Therefore, this study aims to (1) produce a valid instrument in measuring the problem solving abilities of physics and nationalism, and (2) knowing the quality of instruments that have been developed.

\section{Problem Solving Ability}

Problem solving ability is one of the thinking abilities where individuals use their initial knowledge, skills, and understanding that have been obtained before to solve situations that are unfamiliar (Carson, 2007: 7). Problem solving ability can also be interpreted as the ability of an individual in the process of obtaining information as an effort to find solutions to a problem (Santrock, 2011)

Problem solving ability is used when solving a problem that you want to solve is not clear. If this ability continues to be trained, it will help a person to improve long-term memory related to problems and solutions (Kizilirmak, Wiegmann, \& RichardsonKlavehn, 2016). In addition, the problem solving process can also encourage students to be able to actively participate, both in the learning process and in matters relating to the problems of everyday life (Nozari \& Slamlan, 2014)

In the field of physics, the process of solving physics problems will certainly be related to the concept of physics. Most students can receive knowledge related to physical matter, but it is difficult to apply that knowledge (Gamze, Caliskan, \& Erol, 2008). 
Hegde and Meera (2012) revealed that training explicitly in solving physics problems can help students to obtain the required skills.

Santrock (2011) reveals that there are four stages so that the process of problem solving in general can run effectively, namely: (a) finding and limiting problems, (b) developing solutions, (c) evaluating solutions, and (d) thinking about and redefining problems and solution from time to time. Furthermore, Docktor, Strand, Mestre, and Ross (2015) stated that there five stages conducted in the process of solving physics problems, namely (a) focusing the problem, (b) describing its relation to the concept of physics, (c) planning solutions, (d) implementing the plans that have been made, and (e) evaluating solutions.

In addition, Sujarwanto, Hidayat, and Wartono (2014) propose solving physics problems with steps including: (1) identifying relevant concepts, where students know the problem and use the condition to determine the variable being asked, (2) set up problems, where students determine the equations that are suitable for solving problems, (3) execution of solutions, where students perform mathematical operations to find solutions, (4) evaluation answers, where students check units. Furthermore, Mustofa and Rusdiana (2016) also describe indicators of problem solving which consist of: (1) describing variables that are known to the problem, (2) writing the concepts used, (3) using variables in applying concepts and (4) checking and evaluating solutions. Meanwhile, Doyan and Sukmantara (2014) suggested that the ability of physics problem solving includes four criteria, namely: (1) describing known data (2) describing problems that must be found solutions, (3) implementing solutions, and (4) evaluating solutions. Based on previous explanations, the results of the synthesis indicators of problem solving ability measured in this study is presented in Table 1.

Table 1

Indicators of Problem Solving Ability

\begin{tabular}{cl}
\hline No & \multicolumn{1}{c}{ Indicators } \\
\hline 1 & Describe variables known to the problem \\
2 & Determine the equations that are suitable for solving problems \\
3 & Substitute known values to equations \\
4 & Evaluate solutions \\
\hline
\end{tabular}

\section{Nationalism}

In language, nationalism derived from the word national and ism which mean the nation and understanding respectively, so that nationalism means understanding nationality. The understanding referred to the awareness of loving homeland, having a sense of nationality, and maintaining the honor of the nation (Listiyarti, 2007).

Mikail (2014) explained that the characteristics of a sense of nationalism are embedded because it is driven by many similarities in terms of history, culture, right-living, governing laws, and freedom of action to participate in the economy. This opinion is in line with Smith's thinking (2010: 37) which views nationalism as an ideology, culture, and religion of a nation that arises because of the feeling of shared interests and the importance of living together as an independent nation. 
Regarding the Indonesian context, nationalism refers more to attitudes that reflect the personality of Indonesian cultural values as an effort to realize the ideals of being a nation to become an independent and sovereign country (Khoiriyah, 2017). As a multicultural country and has diversity in various aspects of life, Indonesia is very vulnerable to the threat of globalization. Therefore, it requires efforts in uniting every element of the nation in order to avoid the threat of declining nationalism. The spirit of nationalism shown by citizens will have a positive impact on the unity of the nation to work together to realize a common goal (Santiago, 2012).

The path of education can be used as a pathway in efforts to increase public awareness about nationalism. One of them is by developing learning studies that emphasize nationalist values through the selection of learning methods, models, or media that are integrated with learning in schools (Khoiriyah, 2017).

One way that can be done to maximize students' nationalism is through out-of-school programs. Ishaq (2011) states that there are several out-of-school programs that can be carried out to foster nationalism, including: (1) increasing courage to defend the country, where citizens are physically guided to find enemies, work, and teach, (2) national cultural preservation, namely encourage citizens to try to find the cause of the decline of Indonesian culture and then be guided to find ways to preserve it through various media, (3) the use of Indonesian products, where citizens are involved in compulsory education in order to increase interest in using domestic products; take education, and (6) strengthen participation in building or maintaining infrastructure.

In addition, Yasa (2012) conducted a research to develop an instrument for measuring nationalism in the form of a Likert scale. The aspects of nationalism are divided into tolerance, cooperation, and responsibility. Tolerance aspects are formed by indicators of mutual respect, restraint, and accepting differences. The aspect of cooperation includes mutual assistance, caring for others, and being willing to sacrifice. As well as aspects of responsibility that have indicators of awareness of obligations, compliance with the law, and loving domestic products.

Furthermore, Nurhayati (2013) explained that the indicators of nationalism are: a) safeguarding and protecting the country, b) willing to sacrifice, c) preserving Indonesian culture, d) loving the homeland, e) proud of speaking Indonesian, and f) upholding human values. While Soegito (2006) wrote in his book that some indicators of nationalism can be seen from the love of the homeland, the willingness to sacrifice, the unity shown, and perseverance. Based on previous explanations, the results of the synthesis indicators of nationalism measured in this study is presented in Table 1 
Table 2

Indicators of Nationalism

\begin{tabular}{lll}
\hline No & Aspect & Indicator \\
\hline 1 & $\begin{array}{l}\text { Love the } \\
\text { country }\end{array}$ & $\begin{array}{l}\text { Proud to speak Indonesian } \\
\text { Love domestic products } \\
\text { Upholding human values }\end{array}$ \\
\hline 2 & Tolerance & $\begin{array}{l}\text { Accept differences } \\
\text { Mutual trust }\end{array}$ \\
\hline 3 & Cooperation & $\begin{array}{l}\text { Awareness of rights and obligations } \\
\text { Comply with the law }\end{array}$ \\
\hline
\end{tabular}

\section{METHOD}

\section{Research Method}

This research uses development research methods adapted from Mardapi and Oriando ; Antonio (2008, 1998). The research method consists of four stages, namely: (1) the design of the test, which includes the determination of test objectives, the determination of competencies to be achieved, (2) preparation of tests, which includes the preparation of test's blueprint, writing test items, preparing scoring guidelines, item validation, as well as revision of validation results, (3) test trials, which include the determination of the trial subject, the implementation of the trial, and analysis of the results of the trial data, and (4) the preparation of valid instruments

\section{Research Subject}

The subjects of this study were students, experts, physics teachers and practitioners. There were 250 students of class XII MIA from SMAN 1 Gowa and SMAN 4 Jeneponto, South Sulawesi, who were involved in empirical validation. The number of samples is in accordance with the minimum sample size requirement that must be taken in the analysis of the SEM (Structural Equation Modeling) model, which is 100 to 200 (Hair, Tatham, Anderson, \& Black, 1998). The sample was chosen in a random cluster with the consideration that the students had carried out physics learning that had been designed before by the researcher. While content validation involved two expert lecturers, three physics teachers, and four peers.

\section{Data Analysis}

The instruments developed were test and non-test instruments. The test instrument is used to measure the ability to solve physics problems consisting of 10 numbers in the form of essays. While the non-test instrument in the form of a questionnaire was used to measure nationalism consisting of 35 questions arranged in the form of a Likert scale.

Reliability testing is done using the QUEST program by reading the output summary of item estimates and summary of case estimates. Interpretation of instrument reliability values is done by comparing the results with the KR-20 model in accordance with Table 3. 
Table 3

Interpretation of Reliability Values

\begin{tabular}{ll}
\hline Reliability Value & Interpretation \\
\hline $0,00-0,20$ & Low reliable \\
$0,20-0,40$ & Less reliable \\
$0,40-0,60$ & Sufficient \\
$0,60-0,80$ & Reliable \\
$0,80-1,00$ & Very reliable \\
\hline
\end{tabular}

The validity of the instrument was obtained through content and empirical validation. Content validation was done through validation by experts consisting of lecturers, teachers and peer reviewers. Validators will be given validation assessment instruments to conduct quantitative and qualitative assessments related to material, construction and language. Quantitative assessment was obtained based on the scores given by the validator with assessment categories from 1 to 4 on each item assessed by referring to the achievement score indicator. The results of the quantitative assessment given will be analyzed using the Aiken's V formula as seen in equation (1),

$$
V=\frac{\sum s}{[n(c-1)]}
$$

where $n$ is the number of rater, $c$ is the number of category, $l$ is the lowest score in the scoring category, $r$ is the score given by rater. The value of $s$ can be calculated using the equation (2).

$$
s=r-l
$$

(Azwar, 2012)

The quantitative data obtained based on the expertise of the experts is then changed in qualitative form to determine the quality of the instruments that have been developed. Qualitative assessment is based on the categories presented in Table 4.

Table 4

Category of Validity Quality

\begin{tabular}{ll}
\hline Validity & Criteria \\
\hline $0,8<\mathrm{V} \leq 1,0$ & Very Good \\
$0,6<\mathrm{V} \leq 0,8$ & Good \\
$0,4<\mathrm{V} \leq 0,6$ & Sufficient \\
$0,2<\mathrm{V} \leq 0,4$ & Low \\
\hline
\end{tabular}

After going through the content validation stage, the instrument was then tested to obtain empirical validation data involving 250 students. Data obtained from the results of trials were then analyzed using the QUEST program with the PCM model (Adams \& Khoo, 1996). Data processed is politomus data because the instruments used are essays and questionnaires with four categories. The QUEST program output will show the analysis in the form of: (1) goodness of fit on the PCM model, with good categories if the MNSQ INFIT values are in the range of $0.77-1.30$, (2) the difficulty level of the questions, with good categories if the values obtained are in the range of $-2 \leq b \leq+2$, and (3) reliability, with good categories if the values obtained are in the range of $0.6-$ 1.0 . 


\section{FINDINGS AND DISCUSSION}

At the test design stages, several activities have been performed so that it is obtained (1) test subjective: to measure students' problem solving in physics and nationalism, (2) competencies to be achieved is basic competence (KD) 3.10 which is related to sound wave. The selection of this topic is based on the results of observations and semistructured interviews conducted by researchers with schools, teachers, and students.

At the preparation of the test stage, the blueprint and item of test were prepared. The blueprint of problem solving and nationalism instrument can be seen in Table 5 and Table 6 respectively.

Table 5

Blueprint of Problem Solving Instrument

\begin{tabular}{llll}
\hline No. & Criteria & Amount of Item & Item Number \\
\hline 1 & Compliance with the indicator & 2 & 1,2 \\
2 & Instrument completeness & 2 & 3,4 \\
3 & Construction & 4 & $5,6,7,8$ \\
4 & Suitability of content / substance & 3 & $9,10,11$ \\
5 & Linguistic & 3 & $12,13,14$ \\
\hline \multicolumn{2}{l}{ Total Items } & 14 & \\
\hline
\end{tabular}

Table 6

Blueprint of Nationalism Instrument

\begin{tabular}{|c|c|c|c|}
\hline No & Aspect & Indicator & Item Number \\
\hline \multirow{4}{*}{1.} & \multirow{4}{*}{ Content } & $\begin{array}{l}\text { The suitability of the question indicators with the } \\
\text { competencies to be achieved }\end{array}$ & 1 \\
\hline & & $\begin{array}{l}\text { The suitability of the question indicators with the } \\
\text { subject related to music nationalism }\end{array}$ & 2 \\
\hline & & $\begin{array}{l}\text { The suitability of items with the characteristics of } \\
\text { students in nationalism }\end{array}$ & 3 \\
\hline & & Item construction & 4 \\
\hline \multirow[b]{2}{*}{2.} & \multirow[b]{2}{*}{ Linguistic } & The correct use of language & 5 \\
\hline & & $\begin{array}{l}\text { The accuracy of the sentences used does not cause } \\
\text { double interpretation }\end{array}$ & 6 \\
\hline
\end{tabular}

The instruments developed are physics problem solving ability test instrument consists of 10 number essay questions and nationalism questionnaire consists of 35 items arranged in the form of a Likert scale. Furthermore, the problem solving instrument developed was also equipped with rubric scoring of 1-4.

At the test trial stage, the instrument tested to 250 high school students which were selected randomly using cluster random sampling. Students who are subjects of the trial have already obtained the material to be tested. The test participants' answers were assessed and then analysed. Trial analysis is performed to obtain good test instrument characteristics. Analysis was conducted using QUEST program, and based on item response theory (IRT) by applying the model of Partial Credit Model (PCM). 


\section{Content Validity}

The quality of the instrument can be seen from the level of validity and reliability. The test instrument developed consisted of test instruments and non-test instruments. The test instrument consisted of 10 essay numbers used to measure problem solving abilities. Whereas the non-test instrument in the form of a nationalism measurement questionnaire includes 35 numbers arranged in the form of a Likert scale consisting of several answer choices, which strongly agree, agree, disagree, and strongly disagree for each item statement. Both of these instruments were developed by referring to the 2013 curriculum syllabus. The results of content validity of problem solving ability instruments are presented in Table 7.

Table 7

Result of Content Validity of Problem Solving Instrument

\begin{tabular}{ccc}
\hline Item & Validity & Category \\
\hline 1 & 1,00 & Very Good \\
2 & 1,00 & Very Good \\
3 & 1,00 & Very Good \\
4 & 1,00 & Very Good \\
5 & 1,00 & Very Good \\
6 & 1,00 & Very Good \\
7 & 1,00 & Very Good \\
8 & 1,00 & Very Good \\
9 & 1,00 & Very Good \\
10 & 1,00 & Very Good \\
\hline
\end{tabular}

Based on the data presented in Table 7 , it can be seen that the validity of each item in the instrument that has been validated by experts is 1.00. Based on the reference in Table 4, it can be concluded that the instrument developed for measuring the ability of physics problem solving is in a very good and valid category to be used. The results of the validation analysis of the nationalism measurement questionnaire are presented in Table 8.

Table 8

Result of Content Validity of Nationalism Instrument

\begin{tabular}{llll}
\hline Aspect & Indicator & Validity & Category \\
\hline \multirow{5}{*}{ Content } & $\begin{array}{l}\text { Suitability of instrument indicators with competencies } \\
\text { to be achieved }\end{array}$ & 1,00 & Very Good \\
\cline { 2 - 4 } & $\begin{array}{l}\text { Suitability of instrument indicators with sound wave } \\
\text { to improve nationalism }\end{array}$ & 1,00 & Very Good \\
\cline { 2 - 5 } & $\begin{array}{l}\text { Suitability of items with characteristics of students in } \\
\text { nationalism }\end{array}$ & 1,00 & Very Good \\
\cline { 2 - 5 } Language & Construction of items & 1,00 & Very Good \\
\cline { 2 - 5 } & $\begin{array}{l}\text { Useper use of language } \\
\text { interpretations }\end{array}$ & 1,00 & Very Good \\
\hline
\end{tabular}

Based on the data presented in Table 8, it can be seen that the validity of the nationalism questionnaire that has been validated by experts shows a value of 1.00 for each aspect 
measured. Based on the reference in Table 4, it can be concluded that the questionnaire developed is in a very good and valid to be used.

\section{Goodness of Fit}

The instrument trial involved 250 randomly selected students to obtain data from empirical validation. The data obtained were analyzed using the IRT analysis of the PCM model using the QUEST program. The results of instrument's goodness of fit are shown in Figure 1 and Figure 2.

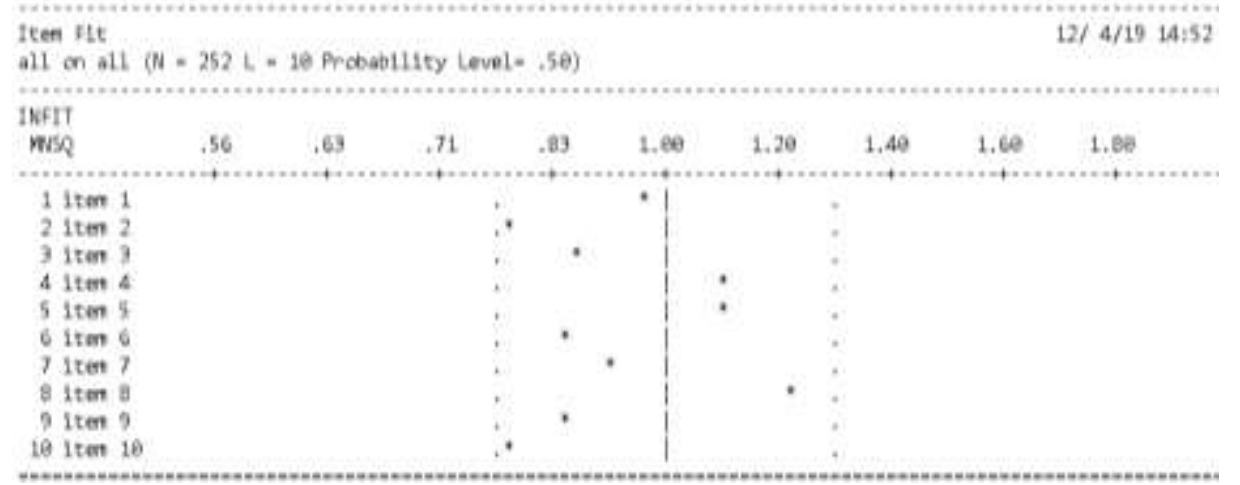

Figure 1

Goodness of Fit of Problem Solving Instrument

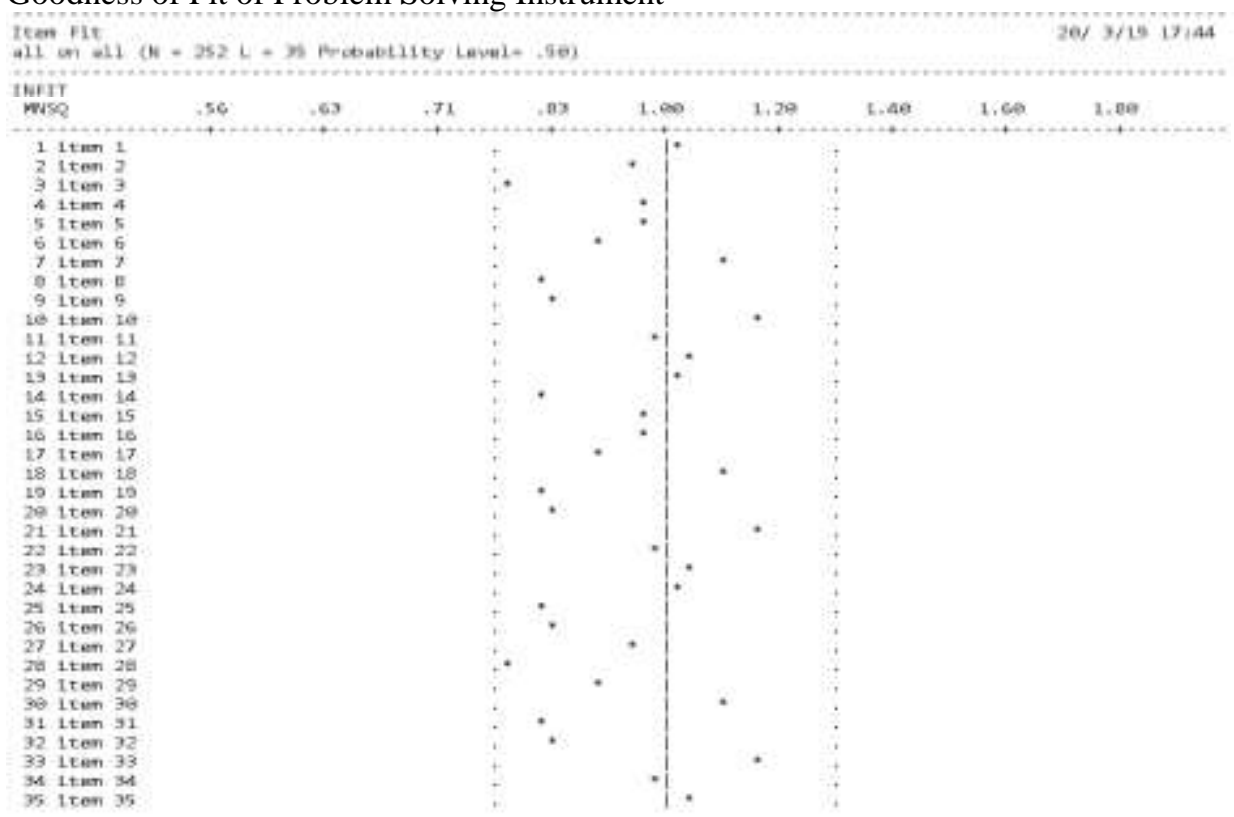

Figure 2

Goodness of Fit of Nationalism Questionnaire 
Based on the results of the IRT analysis shown in Figure 1, it can be seen that all items in the problem solving ability and nationalism measurement instruments are in the MNSQ INFIT range, which is $0.77-1.33$. In both instruments there are also a number of items whose INFIT MNSQ values refer to 1.00 where the best range of goodness of fit is the value 1 . This means that all items used in measuring problem solving ability and nationalism fit the PCM model (Rasch Model).

\section{Reliability}

The results of tests on physics problem solving ability and nationalism questionnaires' reliability show the summary of items estimates and summary case estimates as presented in Table 9. Based on the data shown in Table 7, both physical problem solving ability tests and nationalism questionnaires have item reliability values which is in the range of $0.60-0.80$, while the case reliability value is in the range of $0,80-1,00$. Thus, it can be concluded that the two instruments are in the reliable category for item reliability and are very reliable for case reliability

Table 9

Estimated Reliability of Instruments

\begin{tabular}{lll}
\hline \multirow{2}{*}{ Reliability } & Instrument \\
\cline { 2 - 3 } & Physics Problem Solving Ability & Nationalism Questionnaire \\
\hline Summary of case estimate & 0,91 & 0,98 \\
Summary of item estimate & 0,72 & 0,77 \\
\hline
\end{tabular}

\section{Item Difficulty Level}

The QUEST output can also show the level of difficulty of the item. The difficulty level of the item has a good category if the value obtained ranges from -2 to +2 . The difficulty level item in the problem solving ability problem is presented in Figure 3. In Figure 3 it can be seen that all the items in the problem solving ability are in the range between -2 to +2 . The easiest item is item number 1 with a difficulty level of -0.88 , while the most difficult item is number 8 with a difficulty level of 1.81 . Although the value obtained is not balanced between the easiest and most difficult items, this value is still acceptable because it is still in the range of -2 to +2 . Therefore, all the items in the problem solving ability are in the good category in terms of the level of difficulty of the item. 


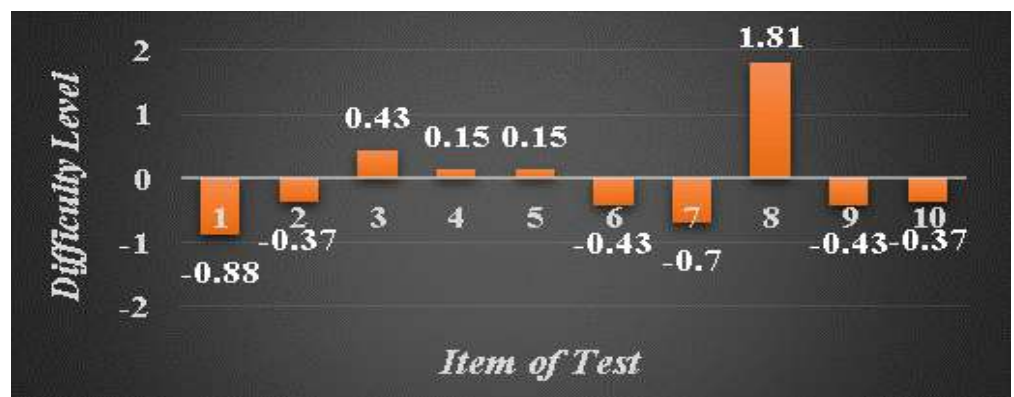

Figure 3

Item Difficulty Level of Problem Solving Ability Instrument

The item difficulty level of nationalism measurement instruments is not displayed in the results of this study. This is because the instrument is in the form of a questionnaire consisting statements that do not contain right or wrong answers. Therefore, the items in this questionnaire do not have the level of difficulty required by the instrument of cognitive measurement.

Overall, the instruments developed consisted of two instruments. The instrument used in measuring cognitive abilities in the form of problem solving abilities was developed in the form of written tests. This test consisted of 10 essay questions that students had to complete in stages. In addition, the affective aspect measurement test was developed in the form of a questionnaire measuring nationalism. The questionnaire consisted of 35 statements whose answers varied and were analyzed on a Likert scale.

The instrument developed was first validated by experts, physics teachers, and peers. After a revision based on the validator's suggestion, the instrument was then tested on 250 high school students for empirical testing. The results of data analysis on the instrument show that: (a) 10 items match the PCM model for the instrument of problem solving ability test and 35 items match the PCM model for the questionnaire of nationalism, (b) the item reliability for problem solving ability and nationalism are respectively 0,72 and 0.77 are included in the reliable category, (c) the level of difficulty items about problem solving abilities are in the range of -2 to +2 so that they are included in the good category. The results obtained are in accordance with the categories set by Adam and Khoo (1996). Therefore, both instruments are valid to be used in learning process.

\section{CONCLUSION}

The conclusions of this study are: (1) The instruments developed are in the valid category based on qualitative and quantitative assessments with validity value of 1,00 in each item measured. Therefore, they are feasible to be used in testing. (2) Instruments developed in accordance with Partial Credit Model (PCM). (3) Both instrument developed are reliable (4) the difficulty level of items in problem solving ability instrument have good criteria which means that is acceptable for measuring problem 
solving ability. Furthermore, as a suggestion for other researchers who want to continue or do other research related to this research, it is better to conduct the validation stage more.

\section{REFERENCES}

Adams, R. J., \& Khoo, S. T. (1996). Quest: The interactive test analysis system version 2.1. Victoria: The Australian Council for Educational Research.

Angell, C., Kind, P. M., Henriksen, E. K., \& Guttersrud. (2008). An empiricalmathematical modelling approach to upper secondary physics. Phy Edu, 43(3), 256-264

Azwar. S,. (2012). Reliabilitas dan Validitas. Pustaka Pelajar: Yogyakarta

Carson, G. S. (2007). Fisika. Jakarta: Grasindo.

Chotimah, U. (2010). Pengembangan Instrumen Penilaian Domain Afektif Pada Matapelajaran PKn di Sekolah Menengah Pertama. Laporan Penelitian http://eprints.unsri.ac.id/1076/.

Docktor, J. L., Strand, N. E., Mestre, J. P., \& Ross, B. H. (2015). Conceptual problem solving in high school physics. Physical Review Special Topics - Physics Education Research, 11(2). doi: 10.1103/PhysRevSTPER.11.020106.

Gamze, S. S., Caliskan, \& Erol, M. (2008). The effect of problem solving instruction on physics achievement, problem solving performance and strategy. Lat Am.J.Physics Education, 2(3), 151-166.

Hair, J. F., Tatham, R. L., Anderson, R. E., \& Black, W. (1998) Multivariate data analyisis. New Jersey: Prentice Hall

Hegde, B., \& Meera, B. (2012). How do they solve it? An insight into the learner's approach to the mechanism of physics problem solving. Physical Review Special Topics - Physics Education Research, 8(1). doi: 10.1103/PhysRevSTPER.8.010109.

Hikmah, \& Cholisin, (2017). Pembelajaran Pendidikan Kewarganegraan Sebagai Proses Transformasi Nasionalisme di Kalangan Siswa. J Pendi Kewargenaraan dan Hukum.

Ishaq. (2011). Pembinaan Nasionalisme Pemuda Perbatasan Melalui Program Pendidikan Luar Sekolah. Jurnal Ilmu Pendidkan, Jilid ,17(6), 459-468.

Khoiriyah, N. (2017). Model Pendidikan Karakter Berbasis Nilai-Nilai Nasionalisme dan Agama di SMA Nasima Semarang. Yogyakarta: Universitas Negeri Yogyakarta.

Kizilirmak, J. M., Wiegmann, B., \& Richardson-Klavehn, A. (2016). Problem solving as an encoding task: A special case of the generation effect. Journal of Problem Solving, 9. doi: 10.7771/1932-6246.1182.

Listiyarti, R. (2007). Pendidikan Kewarganegaraan. Jakarta: Esis

Mardapi, \& Djemari. (2008). Teknik Penyusunan Instrumen Tes dan Nontes. Yogyakarta: Mitra Cendekia Press. 
Mikail, E. H. (2014). Nationalism concept and Turkish nationalism. International Journal of Bussiness and Social Science, 5, 87-90

Mustofa, M., \& Rusdiana, D. (2016). Profil Kemampuan Pemecahan Masalah Siswa Pada Pembelajaran Gerak Lurus. J Peneli dan Pengembangn Pendi Fisika, 2(2), 15-22

Naqiyah, M., Rosana, D., Sukadiyono, \& Ernasari. (2019). Developing physics learning tools based on local wisdom in the form of musical instrument of gandrang bulo dance as learning source in sound wave. Journal for the Education of Gifted Young Scientist, 7(3), 609-626. doi: 10.17478/jegys/599902.

Nitko. A. J. (1996). Educational Assessment of Students. Ohio: Merrill an Imprint of Prentice Hall Englewood Cliffs.

Nozari, A. Y., \& Slamlan, H. (2014). The effect of problem-solving teaching on creative thinking among district 2 high school students in Sari City. Sari, Mazandaran, Iran: University of Medical Sciences.

Nurhayati, Y. (2013). Pengaruh Upacara Bendera Terhadap SIkap Nasionalisme di SMP Negeri 14 Bandung. Bandung: Universitas Pendidikan Indonesia

Oriondo, L. L., \& Antonio. E. M. D. (1998). Evaluating educational outcomes (test, measurement and evaluation). St. Florentino: Rex Printing Company.

Pemerintah Republik Indonesia. (2017). Permendikbud No. 23 Tahun 2016 tentang Standar Penilaian Pendidikan. Jakarta: Kementrian Pendidikan dan Kebudayaan.

Pemerintah Republik Indonesia. (2017). Permendikbud No. 22 Tahun 2016 tentang Standar Proses Pendidikan Dasar dan Menengah. Jakarta: Kementrian Pendidikan dan Kebudayaan.

Purwanto. (2007). Instrumen Penelitian Sosial dan Penidikan. Yogyakarta: Pustaka Belajar.

Reni, A., Sopyan, A., \& Hindarto, N., (2013). Pengembangan Self Assessment Sebagai Alat Evaluasi Pendidikan Karakter Berbasis Konservasi Pada Mahasiswa Pendidikan Fisika FMIPA UNNES. Unnes Phy Edu J, 2(3), 40-46. doi: 10.15294/upej.v2i3.2927.

Santiago, J. (2012). Secularitation and nationalism: A critical review. Social Compass, 59(1), 3-20

Santrock, J. W. (2011). Educational psychology. New York: McGraw-Hill Company

Sinaga, N. (2016). Pengembangan tes kemampuan pemecahan masalah dan penalaran matematika siswa SMP kelas VIII. PYTHAGORAS: Jurnal Pendidikan Matematika, 11(2), 169-181. doi: 10.21831/pg.v11i2.10642.

Smith, A. D. (2010). Nationalism: Theory, ideology, history. Cambridge: Polity Press.

Sujarwanto, E., Hidayat, A., \& Wartono. (2014). Kemampuan Pemecahan Masalah Fisika Pada Modeling Instruction Pada Siswa SMA Kelas XI. J Pendi IPA Ind, 65-78 
Soegito, A. T. (2006). Pendidikan Pancasila. Semarang: UNNES Press

Hidayat, T., Susilaningsih, E., \& Cepi, K. (2018). The effectiveness of enrichment test instruments design to measure students' creative thinking skills and problem-solving. Thinking Skills and Creativity, 29, 161-169. doi: 10.1016/j.tsc.2018.02.011.

Widoyoko, E. P. (2014). Evaluasi Program Pembelajaran. Pustaka Pelajar. Yogyakarta.

Yasa, I M. S. (2012). Pengembangan Alat Ukur Sikap Nasionalisme Pada Siswa RSBI SMA Negeri 1 Gianyar Tahun Pelajaran 2011-2012. Jurnal Ilmiah Pendidikan dan Pembelajaran Ganesha, 2(2). 